\title{
PNEUMOBIL GÖRDÜLÉSI ELLENÁLLÁSÁNAK MÉRÉSE
}

\section{MEASURING THE ROLLING RESISTANCE OF PNEUMOBILE}

\author{
Szeszák Bence Márk ${ }^{1}$, Juhász György², Sziki Gusztáv Áron ${ }^{3}$, Nagyné Kondor Rita ${ }^{4}$, \\ Sütő Tamás Sádor ${ }^{5}$, Veszelszki Krisztián József ${ }^{6}$. \\ ${ }^{1}$ Debreceni Egyetem Müszaki Kar, Gépészmérnöki Tanszék, 4028 Magyarország, \\ Debrecen, Ótemetö utca 2-4.; 0036202499574, szeszakbence@gmail.com \\ ${ }^{2}$ Debreceni Egyetem Müszaki Kar, Gépészmérnöki Tanszék, 4028 Magyarország \\ Debrecen, Ótemetö utca 2-4., juhasz@eng.unideb.hu \\ ${ }^{3}$ Debreceni Egyetem Müszaki Kar, Alaptárgyi Tanszék, 4028 Magyarország Debre- \\ cen, Ótemetö utca 2-4., szikig@eng.unideb.hu \\ ${ }^{4}$ Debreceni Egyetem Müszaki Kar, Alaptárgyi Tanszék, 4028 Magyarország Debre- \\ cen, Ótemetö utca 2-4., rita@eng.unideb.hu \\ ${ }^{5}$ Debreceni Egyetem Müszaki Kar, Gépészmérnöki Tanszék, 4028 Magyarország \\ Debrecen, Ótemető utca 2-4., suto.tamas28@gmail.com \\ ${ }^{6}$ Debreceni Egyetem Müszaki Kar, Gépészmérnöki Tanszék, 4028 Magyarország \\ Debrecen, Ótemetö utca 2-4., vkrisz992@gmail.com
}

\begin{abstract}
In this publication we present a vehicle dynamic model and the motion of equation for pneumobiles. One of the input parameters of the model is the rolling resistance coefficient of the tyres. The present publication describes the experimental set-up and work in the course of which the above coefficient was measured and the effect of tyre pressure on rolling resistance was analyzed. During the measurement, we examined the effect of tyre pressure on rolling resistance, even when the vehicle in unloaded and in loaded state.
\end{abstract}

Keywords: rolling resistance, pneumobile, alternative powered vehicle, Spider8 measuring system, compressed air.

\section{Összefoglalás}

A cikk során bemutatásra kerül a pneumobil differenciál mozgási egyenlete és a jármü dinamikai modellje. A modell egyik bemenő paramétere a gördülési ellenállási együttható. Jelen kiadványban bemutatjuk az összeállított mérőrendszer felépítését, valamint a mérés menetét, melynek segítségével a fenti együttható értékét határoztuk meg az abroncsban lévő nyomás függvényében. A mérés során megvizsgáltuk a gördülési ellenállás értékét a jármü terheletlen és terhelt állapotban is.

Kulcsszavak: gördülési ellenállás, pneumobil, alternativ hajtású jármü, Spider8 mérörendszer, süritett levegö. 


\section{Bevezetés}

A gördülési ellenállás mérését [1] egy a Debreceni Egyetem Müszaki Karán, a IX. Nemzetközi Aventics Pneumobil versenyre, a DE- Fönix Pneumobil csapat által tervezett és épített pneumobilon végeztük el (1.ábra). A mérés célja a gördülési ellenállás együtthatójának meghatározása volt, ugyanis idáig mint konstans érték szerepelt a szimuláció során.

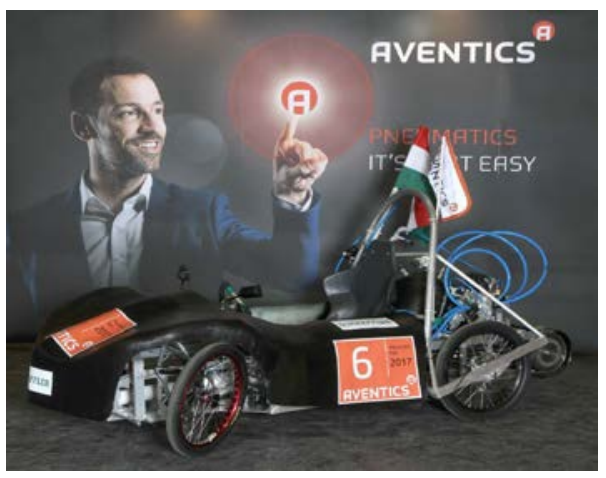

1. ábra. A pneumobil

\section{A pneumobil differenciál mozgá- si egyenlete}

Az elmúlt évek során meghatároztuk a jármü motorjának jelleggörbéit és felírásra került a jármü mozgási egyenlete [2], valamint elkészült a pneumobil dinamikai modellje. A 2. ábrán szemléltetjük a jármü mozgása közben ható erőket.

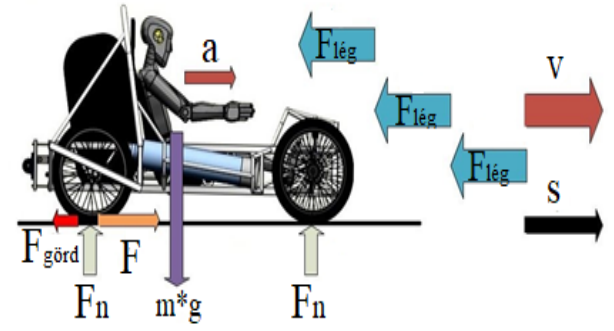

2. ábra. A jármüre ható erők
A 2. ábra alapján a pneumobil mozgási egyenlete az alábbi módon írható fel:

$$
\sum F=F(v)+F_{\text {görd }}+F_{\text {lég }}=m \cdot a
$$

A fenti egyenletböl az $F_{\text {görd }}$ a gördülési ellenállás, amit az alábbi összefüggéssel határozhatunk meg:

$$
F_{\text {görd }}=c \cdot m \cdot g
$$

ahol:

$-F_{\text {görd }}$ a gördülési ellenállás;

$-c$ a gördülési ellenállási együttható;

$-m$ a jármű tömege a terheléssel együtt;

- $g$ a gravitációs állandó.

\section{Anyag és eszközrendszer}

A mérőrendszer 5 egységböl áll össze (3. ábra):

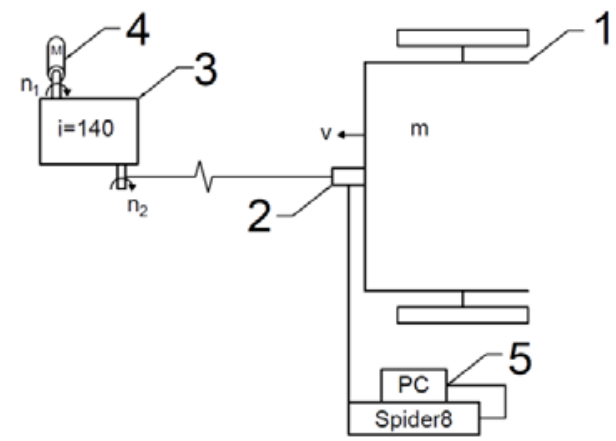

3. ábra. A mérőrendszer sematikus ábrája

Pneumobil (1): A mérést ezen a jármüvön végeztük el.

Erőmérő cella (2): Az erőmérő cellát mereven a jármühöz rögzítettük, ezzel biztosítva a müszer stabilitását. Az erőmérő másik oldalára egy vontató kötelet rögzítettünk, ezzel biztosítva a méröcella egytengelyű terhelését, amely a mérési eredmény pontosságához elengedhetetlen.

Csigahajtómü (3): A jármü egyenletes vontatásához elengedhetetlenül szükséges egy csigahajtómü, mely áttételeinek segítsé- 
gével biztosítja a megfelelő vontató erőt és sebességet.

Meghajtás (4): A hajtóművet és ez által az egész mérörendszert egy Metabo SBE570 típusú fúrógéppel hajtjuk meg. A fúrógépet maximális, $n=3000$ [1/min] fordulatszámon üzemeltetjük.

Mérőrendszer (5): A méréshez használt adatgyüjtő egy Spider8 típusú mérőrendszer összeköttetésben van egy számítógéppel. A számítógépen a mérőrendszerhez tartozó szoftver segítségével tudtuk megjeleníteni és kiértékelni a mérési eredményeket.

\section{Eredmények}

A jármü gördülési ellenállását mértünk olyan módon, hogy az abroncsok nyomását változtattuk Minden nyomásértéken 10 mérést végeztünk. A vizsgálatot terheletlen állapotban [3] négy különböző nyomásértéken mértük. Ezek az 1, 3, 5, és 7 [bar] nyomásértékek voltak. A jármü terhelt állapú vizsgálata [4] során a méréseket 1 [bar] nyomástól indulva 7 [bar] nyomásig vizsgáltuk 0,5 [bar]-os léptékkel haladva. A mérés során a jármű terhelése 650 [N] volt. $\mathrm{Az}$ átlagolásnál figyelembe vett mérési időintervallum: 2-7 [s], mivel ekkor az autó már egyenletes sebességgel haladt. A mért adatokat összesítve átlagot vontunk. Elkészítettük a mérések szórását. Az így kapott eredményeket táblázatba foglaltuk, majd az értékeket grafikonon ábrázoltuk (4., 5. ábra).

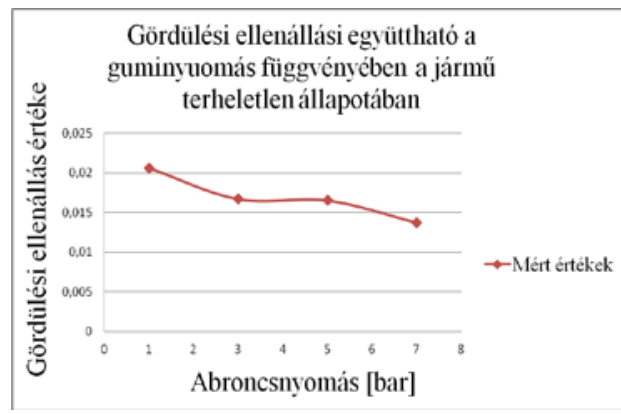

4. ábra. A gördülési ellenállás értéke terheletlen állapotban

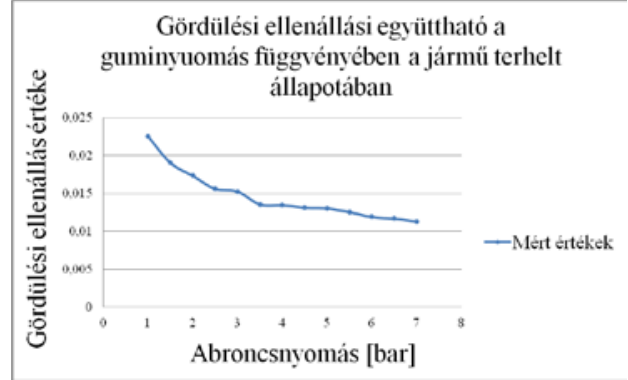

5. ábra. A gördülési ellenállás értéke a jármü terhelt állapotában

\section{5. Összegzés}

A kutatás során méréseket végeztünk annak érdekében, hogy megállapítsuk a pneumobil gördülési ellenállásának értékét. 2014-ben a Debreceni Egyetem Müszaki Karának Gépészmérnöki Tanszékén a Tudományos Diákköri Konferenciájára elkészült egy dolgozat, melyben bemutatásra került a pneumobil differenciál mozgásegyenlete. Az egyenletben a menetellenállások közül néhány, többek között a gördülési ellenállás is, mint konstans tag szerepelt az egyenletben. A mérés célja az érték pontos meghatározása volt a guminyomás függvényében. Erre azért volt szükség, hogy a mozgásegyenletet tovább pontosítva tudjuk szimulálni a jármü menetdinamikai tulajdonságait, így az autó további optimalizálását tudjuk végrehajtani. Bemutatásra került a jármű differenciál mozgásegyenlete, valamint a gördülési ellenállás számításának módja. A mérőrendszer ismertetése után a mérés bemutatása következett. Annak technikai megoldásai, kivitelezése. A mérések segítségével sikerült meghatározni az együttható értékét, és így a továbbiakban már a mért eredményeket felhasználva tudjuk a szimulációt még pontosabbá tenni. A kapott adatokból arra tudunk következtetni, hogy a gördülési ellenállásban nagy szerepet játszik a jármü tömege és az abroncsokban lévő nyomás is. Kutatásunk továbbá azt is igazolta, hogy a jármű súllyal való terhelése 
hatással van a gördülési ellenállás változására. A terhelt állapotban mért értékek átlagának görbéjét matematikai úton sikerült pontosítani [5], és egy közelítő függvényt írni rá (6. ábra).

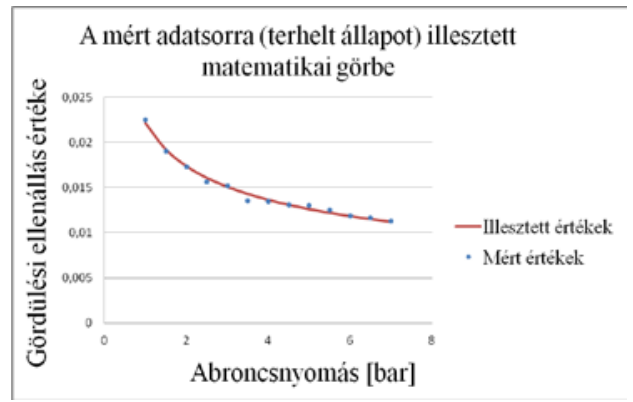

6. ábra. A terhelt állapotban mért értékekre illesztett matematikai görbe

Ezen függvényt felhasználva, a jármü dinamikai szimulációja során a gördülési ellenállási együtthatót tudjuk megállapítani az abroncsokban lévő adott nyomáson, és a szimuláció során felhasználni azt. A mérés során azt a következtetést tudtuk levonni, hogy jelenős az eltérés az 1 és a 7 baros nyomásértékek között. A még pontosabb eredmény végett a méréseket 0,5 baros guminyomás változtatásával végeztük. A mérési eredményekből az tünik ki, hogy bár nem olyan drasztikus a kis léptékek közötti eltérés, mint aközött a két határérték között amit a mérés során választottunk, azonban az mégis nyomon követhető.

\section{Szakirodalmi hivatkozások}

[1] Szeszák, B. M.: Pneumobil gördülési ellenállásának mérése, Szakdolgozat, Debrecen, 2017.

[2] Juhász, B.: Számítógépes program a pneumobil menetdinamikai paramétereinek számításához, TDK, Debrecen, 2014.

[3] Veszelszki, K., Szeszák, B. M.: Pneumobil gördülési ellenállásának vizsgálata, TDK, Debrecen, 2016.

[4] Szeszák, B. M., Sütő, T. S.: Pneumobil gördülési ellenállásának vizsgálata terhelt állapotban, TDK, Debrecen, 2017.

[5] Szíki, G. Á., Juhász, Gy., Nagyné Kondor, R., Szeszák, B. M., Sütő, S. T.: Analysis of the rolling resistance of pneumobiles for vehicle dynamic modelling purpose, Debrecen, 2018. 